\begin{tabular}{l|l|l} 
Jurnal Eksplorasi Akuntansi & Vol. 1, No 1, Seri B, Februari 2019, Hal 198-216
\end{tabular} \mid $\begin{aligned} & \text { ISSN : 2656-3649 (Online) } \\
& \text { http:// jea.ppj.unp.ac.id/index.php/jea/issue/view/2 }\end{aligned}$

\title{
PERSEPSI MINAT MAHASISWA S1 AKUNTANSI TERHADAP KARIR DI BIDANG AKUNTANSI PEMERINTAHAN
} (Studi Empiris pada Mahasiswa S1 Akuntansi Universitas Negeri di Kota Padang)

\author{
Sharly Ramayani ${ }^{1}$, Vita Fitria Sari ${ }^{2}$ \\ 1) Alumni Jurusan Akuntansi Fakultas Ekonomi, Universitas Negeri Padang \\ ${ }^{2)}$ Jurusan Akuntansi Fakultas Ekonomi, Universitas Negeri Padang \\ *Korespondensi: ramayanisharly@gmail.com
}

\begin{abstract}
This reseacrh aims to examine the perception of interest from students towards a career in government accounting. The population in this research are students that year of entry is 2016 and 2015 from UNP and UNAND. The total sample was 310 students. The data used is primary data. The technique of collecting data by questionnaires. The analytical method used is descriptive analysis, inductive analysis and different test analysis. The result showed a 2-tailed significance value is 0,449>0,05. There is no significant difference between students before and after taking government accounting courses but career in government is quite attractive.
\end{abstract}

Keywords: career; government accounting; perception; public sector accounting

How to cite (APA $6^{\text {th }}$ style)

Ramayani, S \& Sari, V. F. (2019). Persepsi Minat Mahasiswa S1 Akuntansi Terhadap Karir di Bidang Akuntansi Pemerintahan (Studi Empiris pada Mahasiswa S1 Akuntansisi Universitas Negeri di Kota Padang). Jurnal Eksplorasi Akuntansi, 1(1) Seri B, 198-216.

\section{PENDAHULUAN}

Hasil penelitian Basuki (1999) menyebutkan bahwa rata-rata mahasiswa memilih jurusan akuntansi didorong oleh keinginana mereka untuk menjadi profesional di bidang akuntansi. Motivasi selanjutnya karena adanya anggapan bahwa profesi akuntan dimasa mendatang akan sangat dibutuhkan oleh banyak organisasi, perusahaan dan pemerintahan khususnya di Indonesia. Akuntansi memegang peranan penting dalam ekonomi, sosial dan pemerintahan dalam menentukan laju perkembangan ekonomi karena informasi akuntansi dan opini dari akuntan sangat berpengaruh dalam pengambilan keputusan yang bersifat keuangan. Keadaan ini menjadikan akuntansi sebagai suatu profesi yang sangat dibutuhkan dalam lingkungan organisasi (Mulyadi, 2001).

Perekonomian yang terus tumbuh membuat potensi ekonomi Indonesia berkembang dan memerlukan peranan akuntan profesional. Akuntan tidak hanya dibutuhkan untuk memenuhi kebutuhan manajemen suatu entitas tetapi juga untuk kebutuhan pertanggungjawaban (accountability) kepada banyak pihak yang memerlukan, hal ini dipengaruhi oleh perkembangan teknologi informasi yang memungkinkan masyarakat untuk menilai dan membandingkan suatu entitas sehingga menuntut penyediaan informasi keuangan (Fauzi, 2002). 
Bagi kepentingan negara akuntansi membantu pemerintah dengan penggunaan keuangan negara yang pada hakikatnya merupakan uang rakyat. Menghindari kesalahan pengambilan keputusan, pemerintah mendasarkan semua keputusan ekonominya pada informasi yang dapat dipertanggungjawabkan. Pertanggungjawaban tersebut membuat pemerintah lebih akurat dalam melaksanakan berbagai aktivitas penyelenggaraan pemerintahannya terutama yang berhubungan dengan transaksi keuangan (Meliali, 2011). Fenomena yang dapat diamati dalam perkembangan sektor publik saat ini adalah semakin kuatnya tuntutan pelaksanaan akuntabilitas publik oleh organisasi sektor publik seperti peemrintahan pusat dan daerah, unit-unit kerja pemerintah, departemen dan lembaga-lembaga negara (Mardiasmo, 2006). Besarnya tuntutan masyarakat terhadap akuntabilitas pemerintahan melahirkan implikasi bagi pemerintah daerah untuk memberikan informasi kepada masyarakat, salah satunya berupa informasi laporan keuangan.

Profesi akuntan saat ini dihadapkan dengan majunya perkembangan teknologi, tetapi profesi akuntan tidak akan tergantikan karena memerlukan analisis, memadukan dana finansial dengan sosial serta memadukan data finansial dengan aspek legal yang hanya bisa dilakukan oleh akuntan. Reformasi yang telah mengubah peran tradisional akuntansi juga menyebabkan perubahan fokus pendidikan akuntansi sektor publik. Pembelajaran akuntansi di perguruan tinggi saat ini lebih difokuskan untuk memenuhi kebutuhan sektor swasta dengan permintaan yang tinggi untuk lulusan yang terampil sehingga pendidikan akuntansi untuk sektor publik menjadi terbatas (Engstrom, 1979). Sadar akan pentingnya ilmu akuntansi sektor publik, perguruan tinggi menjadikan akuntansi sektor publik masuk ke dalam kurikulum pendidikan dalam perkuliahan. Pendidikan sektor publik diajarkan pada mata kuliah akuntansi sektor publik, manajemen keuangan daerah dan akuntansi pemerintah yang diajarkan pada semester yang berbeda.

Engstrom (1979) berpendapat bahwa keputusan perguruan tinggi untuk memperluas dan memperdalam ilmu akuntansi pemerintahan didasarkan pada permintaan lulusan akuntansi dengan pengetahuan sektor pemerintahan akan meningkat dalam waktu dekat. Penelitian yang dilakukan Martin (2017) menyampaikan bahwa pendidikan di jenjang perkuliahan akan mempengaruhi persepsi mahasiswa dalam menentukan karir. Semakin mahasiswa mengerti dengan akuntansi pemerintahan tentu akan semakin menumbuhkan minat untuk berkarir di bidang pemerintahan. Perencanaan karir merupakan hal yang sangat penting untuk menentukan arah kesuksesan (Rasmini, 2007).

Penelitian ini diadopsi dari penelitian yang dilakukan oleh Martin (2017) yang dilakukan di Amerika Serikat. Penelitian ini sama-sama ingin mengetahui bagaimana persepsi mahasiswa akuntansi terhadap berkarir di bidang akuntansi pemerintahan, apakah ada perbedaan persepsi antara mahasiswa yang belum menyelesaikan mata kuliah akuntansi pemerintahan dengan mahasiswa yang telah menyelesaikan mata kuliah akuntansi pemerintahan. Perbedaan penelitian ini dengan penelitian sebelumnya adalah penelitian ini dilakukan di Indonesia dengan periode waktu yang berbeda yaitu tahun 2018 sedangkan penelitian sebelumnya dilakukan di Amerika Serikat pada tahun 2015. Penelitian sebelumnya menggunanakan analisis sensitivitas dengan melihat apakah jenis kelamin dan pengalaman kerja juga mempengaruhi persepsi mahasiswa atau tidak sedangkan penelitian ini tidak menghubungkan jenis kelamin dan pengalaman kerja dengan persepsi mahasiswa karena berdasarkan hasil penelitian Choirunisa (2017) jenis kelamin tidak berpengaruh signifikan terhadap minat menjadi akuntan pemerintahan karena jumlah responden mahasiswa laki-laki dan perempuan berbeda jauh sehingga tidak mencerminkan perbandingan yang seimbang.

Penelitian sebelumnya juga menanyakan pilihan karir apa yang akan dikejar mahasiswa setelah lulus nanti dan ujian sertifikasi apa yang akan mereka ambil (CFE, CGFM, CIA, CMA, 
dan CPA), sedangkan penelitian ini lebih fokus kepada profesi apa yang paling diminati mahasiswa untuk berkarir di bidang akuntansi pemerintahan. Penelitian ini menyediakan beberapa pilihan profesi akuntan khusus untuk lembaga pemerintahan saja.

Berdasarkan uraian di atas maka peneliti tertarik meneliti tentang minat berkarir dengan judul "Persepsi Minat Mahasiswa S1 Akuntansi terhadap Karir di bidang Akuntansi Pemerintahan (Studi Empitis pada Mahasiswa S1 Akuntansi Universitas Negeri di Kota Padang).

\section{REVIEW LITERATUR DAN HIPOTESIS Teori Persepsi}

Persepsi menurut Setiyani (2008) adalah proses dimana individu mengatur dan menginterpretasikan kesan-kesan sensoris mereka guna memberikan arti bagi lingkungan mereka. Proses persepsi dimulai dari diterimanya rangsangan (stimulus) oleh seseorang melalui alat penerimanya (panca indera), dilanjutkan ke pusat susunan syaraf yaitu otak, rangsangan tersebut kemudian diinterpretasikan sehingga individu mengerti dan menyadari apa yang diinderanya.

Robbins (1996) mengemukakan bahwa persepsi berkarir jika individu merasa organisasi atau lembaga tempatnya bekerja menyediakan peluang bagi dirinya untuk dapat memenuhi kebutuhan tujuan karirnya maka individu yang bersangkutan akan membentuk persepsi yang positif mengenai pengembangan karirnya dalam organisasi tersebut. Sebaliknya jika individu merasa organisasi tempatnya bekerja kurang menyediakan peluang bagi dirinya untuk dapat memenuhi kebutuhan dan tujuan karirnya maka individu yang bersangkutan akan membentuk persepsi yang negatif mengenai pengembangan karirnya dalam organisasi tersebut.

\section{Teori Pengharapan (Expectancy Theory)}

Teori dasar dari konsep pemilihan karir yang digunakan sebagai landasan teori adalah teori pengharapan (expectancy theory) yang berhubungan dengan teori motivasi. Teori haraapan memprediksi bahwa karyawan akan mengeluarkan tingkat usaha yang tinggi apabila mereka merasa bahwa ada hubungan yang kuat antara upaya dan kinerja, kinerja dan imbalan, serta imbalan dan sasaran-sasaran pribadi (Vroom,1964).

Kunci dari teori pengharapan menurut Aprilyan (2011) adalah pemahaman sasaran individu dan keterkaitan antara upaya dan kinerja, antara kinerja dan imbalan. Pemilihan karir mahasiswa akuntansi ditentukan oleh pengharapan akan karir yang mereka pilih, apakah karir tersebut dianggap dapat memenuhi kebutuhan individu mereka dan apakah karir tersebut mempunyai daya tarik bagi mereka.

\section{Reformasi Akuntansi Pemerintahan di Indonesia}

Akuntansi pemerintahan atau yang juga dikenal dengan istilah akuntansi sektor publik sudah ada sejak ribuan tahun yang lalu. Akuntansi pemerintahan di Indonesia sudah ada sejak tahun 1959 pada saat pemerintahan orde lama mulai melakukan kebijakan-kebijakan berupa nasionalisasi perusahaan asing yang ditransformasi menjadi Badan Usaha Milik Negara (BUMN).

Akuntansi sektor publik terus berkembang sebagai sebuah alat pengawasan dan pelaporan dalam rangka akuntabilitas publik (Nordiawan, dkk, 2010: 6). Reformasi di Indonesia memberikan dampak yang signifikan dalam perkembangan akuntansi sektor publik. Tuntutan agar pemerintah mengelola secara profesional dan efisien membuka kesadaran setiap orang terutama aparat pemerintah untuk senantiasa menanggapi tuntutan lingkungannya dengan berupaya memberikan pelayanan terbaik secara transparan dan akuntabel. 


\title{
Perkembangan Penelitian tentang Pengajaran Akuntansi Pemerintah
}

Holder (1978) melakukan penelitian terkait pendidikan akuntansi pemerintahan di Amerika Serikat dan menemukan adanya keterbatasan pendidikan sektor publik di perguruan tinggi. Penelitiannya menunjukkan bahwa sebagian besar perguruan tinggi tidak menawarkan pendidikan akuntansi pemerintahan karena kurangnya sumber daya manusia, minat mahasiswa yang rendah, keterbatasan tenaga pengajar dan peluang karir yang rendah. Engstrom (1979) melakukan penelitian serupa di Amerika Serikat dan menemukan beberapa perguruan tinggi terakreditasi memperluas pendidikan ke bidang akuntansi pemerintahan tetapi tidak dapat dilakukan karena kurangnya danadan tenaga pengajar yang berkualitas.

Sims (1979) juga mempelajari permasalahan akuntansi pemerintahan di perguruan tinggi di Australia dan melaporkan bahwa sebagian besar lulusan akuntansi disana hanya mendapat sedikit saja ilmu terkait akuntansi pemerintahan. Satu dekade kemudian Sins kembali melakukan penelitian pendidikan akuntansi pemerintah di perguruan tinggi Australia dan tidak menemukan adanya peningkatan yang signifikan dalam pendidikan akuntansi pemerintahan.

\begin{abstract}
Akuntabilitas
Akuntabilitas (accountability) berarti pertanggungjawaban atau keadaan untuk dipertanggungjawabkan atau keadaan diminta mempertanggungjawabkan (Salim, 1991). Selanjutnya Mahmudi (2007: 11) menjelaskan bahwa akuntabilitas finansial/keuangan adalah pertanggungjawaban lembaga-lembaga publik untuk menggunakan uang publik secara ekonomis, efisien, efektif dan tidak ada pemborosan serta kebocoran dana serta korupsi.

Governmental Accounting Standards Board (GASB) menyatakan bahwa akuntabilitas merupakan dasar pelaporan keuangan di pemerintahan yang didasari oleh adanya hak masyarakat untuk mengetahui dan menerima penjelasan atas pengumpulan sumber daya dan penggunaannya. Akuntabilitas dalam konteks pemerintahan mempunyai arti pertanggungjawaban yang merupakan salah satu ciri dari terapan good governance.
\end{abstract}

\section{Karir}

Menurut Handoko (1996: 121) karir adalah semua pekerjaan atau jabatan yang dipegang selama kehidupan kerja seseorang. Pemilihan karir merupakan suatu cara atau usaha seseorang mengambil satu diantara banyak jabatan atau pekerjaan yang memberikan harapan untuk maju dan sesuai dengan yang di inginkan.

\section{Minat}

Suryobroto (1998: 109) menjelaskan minat adalah kecenderungan dalam diri individu untuk tertarik pada suatu objek. Timbulnya minat terhadap suatu objek ini ditandai dengan adanya rasa senang atau tertarik. Minat berkarir adalah suatu pemusatan yang tidak di sengaja yang terlahir dari dalam diri individu untuk mengerti individu dan menuntun aktivitas dimasa yang akan datang. Minat berkarir di bidang pemerintahan banyak dibutuhkan karena pemerintahan Indonesia telah memperketat penerapannya. Seseorang yang berminat terhadap suatu objek sudah tentu ada unsur motivasi didalamnya, motivasi seseorang akan memberikan dorongan untuk mencapai terhadap apa yang ia minati demi memenuhi kebutuhannya.

\section{Pekerjaan di bidang Akuntansi Pemerintahan}

Menurut Mangunwijaya pendidikan di Indonesia melahirkan minat untuk menjadi pegawai pemerintahan karena masih mewarisi mental inlader dari zaman penjajahan dulu, dimana 
kolonial Belanda mendidik orang supaya patuh dan taat pada pemerintah agar bisa menjadi ambtenaar (pegawai pemerintah zaman kolonial) yang merupakan jabatan terhormat kala itu. Pekerjaan di bidang akuntansi memiliki asumsi going concern untuk kelangsungan hidupnya. Pekerjaan di bidang akuntansi pemerintahan saat ini semakin diminati karena adanya tuntutan akuntabilitas yang tinggi sehingga menuntut para akuntan pemerintah untuk dapat bekerja secara lebih profesional dan akuntabel. Adanya tuntutan yang tinggi membuat pemerintah membutuhkan sumber daya manusia yang lebih banyak pula untuk mewujudkan transparansi.

\section{Hipotesis dan Kerangka Konseptual}

Berdasarkan uraian di atas, dapat disimpulkan hipotesis untuk penelitian ini adalah :

Ho: Tidak terdapat perbedaan persepsi minat berkarir di bidang akuntansi pemerintahan antara mahasiswa akuntansi sebelum dan sesudah menyelesaikan mata kuliah akuntansi pemerintahan.

Ha: Terdapat perbedaan persepsi minat berkarir di bidang akuntansi pemerintahan antara mahasiswa akuntansi sebelum dan sesudah menyelesaikan mata kuliah akuntansi pemerintahan.

Dari hipotesis tersebut, maka kerangka konseptual untuk penelitian ini adalah :

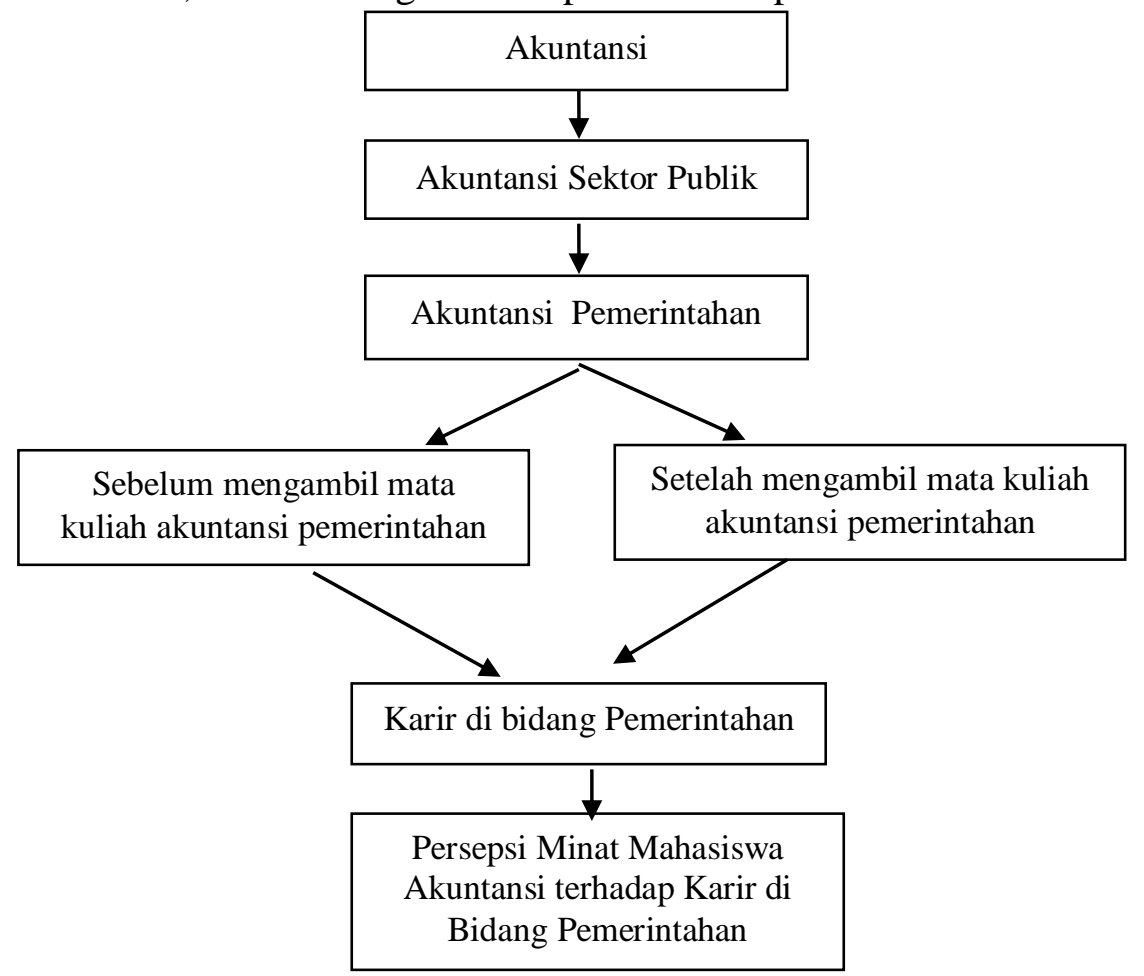

Gambar I . Kerangka Konseptual

\section{METODE PENELITIAN}

\section{Jenis Penelitian}

Jenis penelitian yang digunakan dalam penelitian ini adalah penelitian deskriptif-komparatif dengan pendekatan kuantitatif, yaitu penelitian dengan data kuantitatif yang kemudian diolah dan dianalisis untuk diambil kesimpulan. 


\section{Populasi dan Sampel}

Populasi dalam penelitian ini adalah mahasiswa jurusan S1 akuntansi universitas negeri di kota Padang. Sampel dalam penelitian ini adalah mahasiswa jurusan akuntansi S1 tahun masuk 2015 dengan asumsi sudah banyak memperoleh pemahaman mengenai akuntansi pemerintahan dan mahasiswa tahun masuk 2016 dengan asumsi belum terlalu mengenal akuntansi pemerintahan di Universitas Negeri Padang (UNP) dan Universitas Andalas (UNAND).

\section{Jenis dan Sumber Data}

Jenis dan sumber data yang digunakan dalam penelitian ini adalah data primer berupa kuesioner, yaitu daftar pertanyaan tertulis yang dirumuskan sebelumnya yang diisi oleh mahasiswa sebagai responden.

\section{Metode Pengumpulan Data}

Metode pengumpulan data dalam penelitian ini menggunakan kuesioner yang mengacu pada penelitian yang dilakukan oleh Martin (2015).

\section{Instrumen Penelitian}

Bagian pertama dari penelitian ini menggunakan kuesioner yang dikembangkan oleh McKenzie (1992) dan digunakan oleh Hardnett (2012). Bagian kedua menggunakan kuesioner yang diadaptasi dari penelitian Saeman dan Crooker (1999) tentang pandangan responden terkait akuntansi pemerintahan dari 36 padanan kata. Bagian terakhir dari penelitian ini menyatakan minat mahasiswa jika berkarir di pemerintahan, profesi apa yang paling diminati.

Penelitian dilakukan pada mahasiswa yang sudah menyelesaikan mata kuliah akuntansi pemerintahan dan yang belum menyelesaikan mata kuliah akuntansi pemerintahan untuk melihat apakah ada perbedaan minat profesi sebelum dan sesudah belajar akuntansi pemerintahan.

\section{Pengukuran Penelitian}

\section{a) Persepsi Mahasiswa}

Pengukuran menggunakan skala likert yang terdapat pada kuesioner dengan lima alternatif jawaban masing-masing diberi skor yaitu : Sangat Setuju (SS), Setuju (S), Netral (N), Tidak Setuju (TS), Sangat Tidak Setuju (STS).

\section{b) Mahasiswa yang Sudah dan Belum Menyelesaikan Mata Kuliah Akuntansi Pemerintahan}

Pengukuran untuk mengetahui persepsi mahasiswa yang sudah dan belum menyelesaikan akuntansi pemerintahan dalam penelitian ini menggunakan alat ukur dummy, tujuannya adalah untuk membagi mahasiswa berdasarkan kategori. Pengukuran dummy yang dipakai adalah nilai 1 jika mahasiswa sudah menyelesaikan mata kuliah akuntansi pemerintahan dan nilai 0 jika mahasiswa beluum menyelesaikan mata kuliah akuntansi pemerintahan.

\section{Analisis Uji Coba Instrumen}

\section{a) Uji Validitas}

Uji validitas digunakan untuk mengukur sejauh mana instrumen yang digunakan benar-benar mengukur apa yang harus diukur. Uji validitas menggambarkan bahwa pertanyaan yang digunakan mampu untuk mengungkapkan sesuatu yang dapat dikur (valid). Jika $r_{\text {hitung }}<r_{\text {tabel }}$ maka item tidak valid, sebaliknya jika $\mathrm{r}_{\text {hitung }}>\mathrm{r}_{\text {tabel }}$ maka item valid. 


\section{b) Uji Reliabilitas}

Uji reliabilitas digunakan untuk mengukur apakah instrumen yang digunakan bebas dari kesalahan sehingga diharapkan dapat digunakan dengan aman karena instrumen yang reliabel akan akurat, dapat bekerja dengan baik pada waktu yang berbeda-beda dan kondisi yang berbeda-beda pula.

\section{Teknik Analisis Data}

\section{a) Analisis Deskriptif}

Teknik statistik deskriptif yang digunakan dalam penelitian ini bertujuan untuk menginterpretasikan nilai rata-rata, median, standar deviasi, nilai maksimum dan minimum dari item penelitian.

\section{b) Analisis Induktif}

\section{Uji Persyaratan Asumsi}

1) Uji Normalitas

Uji normalitas dilakukan untuk melihat apakah data yang diperoleh terdistribusi normal atau tidak. Pengujian ini menggunakan metode Shapiro-Wilk dengan $\alpha=0,05$. Jika level signifikan besar dari $\alpha=0,05$ maka data tersebar secara normal. Jika level signifikan kecil dari $\alpha=0,05$ maka tidak tersebar secara normal.

\section{2) Uji Homogenitas}

Uji homogenitas digunakan untuk mengetahui apakah data dari hasil penelitian mempunyai nilai varian yang sama (homogen) yang dilihat pada tabel Test of Homogenity apabila taraf signifikansinya yaitu $\geq 0,05$. Jika taraf signifikansinya $<0,05$ maka data disimpulkan tidak mempunyai nilai varian yang sama atau berbeda (tidak homogen).

\section{3) Analisis Uji Beda}

Uji beda digunakan untuk mengevaluasi perlakuan tertentu pada satu sampel yang sama pada dua periode pengamatan yang berbeda. Dasar pengambilan keputusan untuk menerima atau menolak Ho pada uji ini adalah jika $t_{\text {hitung }}>\mathrm{t}_{\text {tabel }}$ dan (Asymp.Sig) $<0,05$ maka Ho ditolak dan Ha diterima. Jika $t_{\text {hitung }}<\mathrm{t}_{\text {tabel }}$ dan probabilitas (Asymp.Sig) $>0,05$ maka Ho diterima dan Ha ditolak.

\section{HASIL DAN PEMBAHASAN}

Populasi dalam penelitian ini yaitu mahasiswa S1 akuntansi universitas negeri di kota Padang dengan penyebaran kuesioner secara langsung kepada responden. Jumlah kuesioner yang disebar adalah 333, kuesioner yang kembali sebanyak 314 dengan 4 kuesioner tidak dapat diolah. Jumlah kuesioner yang diisi lengkap dan dapat diolah adalah sebanyak 310 kuesioner.

\section{Uji Validitas dan Reliabilitas}

\section{a) Uji validitas}

Jika $\mathrm{r}_{\text {hitung }}>\mathrm{r}_{\text {tabel }}$ maka data dikatakan valid dimana $\mathrm{r}_{\text {tabel }}$ untuk $\mathrm{N}=155$ adalah 0,1326 . Berdasarkan hasil pengelolaan data didapatkan nilai Corected Item-Total Collection terkecil untuk masing-masing item pernyataan semuanya di atas $r_{\text {tabel }}$, ini menunjukkan seluruh item pernyataan adalah valid. 
Tabel 1

Hasil Uji Validitas

Nilai Corected Item-Total Collection Terkecil

\begin{tabular}{ccc}
\hline Instrumen Penelitian & $\begin{array}{c}\text { Nilai Corected Item-Total } \\
\text { Collection Terkecil }\end{array}$ & Keterangan \\
\hline Mahasiswa tahun masuk 2016 & 0,531 & Valid \\
Mahasiswa tahun masuk 2015 & 0,537 & valid \\
\hline
\end{tabular}

Sumber : Data primer yang diolah, 2018

\section{b) Uji Reliabilitas}

Suatu kuesioner dikatakan reliabel atau andal jika jawaban seseorang terhadap pernyataan adalah konsisten dari waktu ke waktu, untuk mengetahui reliabel atau tidaknya suatu variabel dilakukan uji statistik dengan melihat Cronbach's Alpha dan nilainya harus lebih besar dari 0,6. Berikut merupakan tabel nilai Cronbach's Alpha masing-masing instrumen :

\section{Tabel 2}

Hasil Uji Reliabilitas

Nilai Cronbach's Alpha

\begin{tabular}{ccc}
\hline Instrumen Penelitian & Nilai Cronbach's Alpha & Keterangan \\
\hline Mahasiswa tahun masuk 2016 & 0,759 & Reliabel \\
Mahasiswa tahun masuk 2015 & 0,681 & Reliabel \\
\hline Sumbel
\end{tabular}

Sumber : Data primer yang diolah, 2018

Data ini menunjukkan nilai Cronbach's Alpha di atas 0,60 dengan demikian semua instrumen penelitian dapat dikatakan reliabel.

\section{Uji Asumsi Klasik}

Sebelum data diolah dengan paired sampel T-test maka dilakukan uji asumsi klasik untuk memperoleh keyakinan bahwa data yang diperoleh beserta variabel penelitian layak diolah lebih lanjut.

\section{a) Uji Normalitas}

Uji normalitas untuk dua angkatan yang berbeda tersebut dilakukan dengan uji Shapiro-Wilk dengan taraf signifikansi 0,05, terdapat pada tabel 3 berikut ini :

\section{Tabel 3}

Hasil Uji Normalitas Shapiro-Wilk

\begin{tabular}{lcc}
\hline Instrumen Penelitian & Shapiro-Wilk & Keterangan \\
\hline Mahasiswa tahun masuk 2016 & 0,057 & Normal \\
Mahasiswa tahun masuk 2015 & 0,069 & Normal \\
\hline Sumbal $:$ Dat primer yang
\end{tabular}

Sumber : Data primer yang diolah, 2018

Berdasarkan tabel 3 di atas terlihat bahwa hasil uji normalitas menunjukkan level signifikansi lebih besar dari $\alpha=0,05$ sehingga dapat disimpulkan bahwa semua pernyataan dalam penelitian ini terdistribusi secara normal. 
b) Uji Homogenitas

Hasil uji homogenitas dapat dilihat pada tabel 4 berikut :

Tabel 4

Uji Homogenitas

Test of Homogeneity of Variances

\begin{tabular}{cccc}
\hline Levene Statistic & df1 & Df2 & Sig. \\
\hline 888 & 1 & 308 &, 347 \\
\hline Sumber : Data primer yang diolah, 2018 & &
\end{tabular}

Dari hasil uji homogenitas diketahui bahwa nilai signifikansinya adalah $0,347 \geq 0,05$ maka data mempunyai nilai varian yang sama atau tidak berbeda (homogen). Selanjutnya akan dilakukan analisis data dengan uji Paired Sampel T-test.

\section{Teknik Analisis Data}

a) Analisis Deskriptif

1. Statistik Deskriptif

Tabel 5

Statistik Deskriptif

\begin{tabular}{|c|c|c|c|c|c|c|c|}
\hline \multirow{3}{*}{ No } & \multirow{3}{*}{$\mathbf{N}$} & \multicolumn{3}{|c|}{ Tahun Masuk 2016} & \multicolumn{3}{|c|}{ Tahun Masuk 2015} \\
\hline & & & & & & & \\
\hline & & Mean & SD & Med & Mean & SD & Med \\
\hline 1 & 155 & 3,43 & 1,195 & 4,00 & 3,55 & 1,259 & 4,00 \\
\hline 2 & 155 & 3,09 & 1,113 & 3,00 & 2,72 & 1,102 & 3,00 \\
\hline 3 & 155 & 3,68 & 1,080 & 4,00 & 3,86 & 0,983 & 4,00 \\
\hline 4 & 155 & 3,27 & 1,034 & 3,00 & 3,25 & 0,956 & 3,00 \\
\hline 5 & 155 & 2,83 & 0,959 & 3,00 & 2,99 & 0,947 & 3,00 \\
\hline 6 & 155 & 3,16 & 0,922 & 3,00 & 3,21 & 0,960 & 3,00 \\
\hline 7 & 155 & 3,41 & 1,056 & 3,00 & 3,36 & 1,050 & 3,00 \\
\hline 8 & 155 & 3,81 & 1,105 & 4,00 & 3,48 & 1,124 & 4,00 \\
\hline 9 & 155 & 3,19 & 1,161 & 3,00 & 3,01 & 1,148 & 3,00 \\
\hline 10 & 155 & 3,34 & 0,963 & 3,00 & 3,34 & 1,034 & 3,00 \\
\hline 11 & 155 & 2,76 & 1,177 & 3,00 & 2,52 & 1,113 & 2,00 \\
\hline 12 & 155 & 3,13 & 0,951 & 3,00 & 3,20 & 1,084 & 3,00 \\
\hline 13 & 155 & 3,12 & 1,119 & 3,00 & 2,74 & 1,233 & 2,00 \\
\hline 14 & 155 & 3,28 & 1,143 & 3,00 & 3,41 & 1,049 & 3,00 \\
\hline 15 & 155 & 3,79 & 0,992 & 4,00 & 3,67 & 1,014 & 4,00 \\
\hline 16 & 155 & 3,86 & 0,947 & 4,00 & 3,68 & 1,092 & 4,00 \\
\hline 17 & 155 & 2,55 & 1,255 & 2,00 & 2,54 & 1,164 & 2,00 \\
\hline 18 & 155 & 3,12 & 1,250 & 3,00 & 3,17 & 1,270 & 3,00 \\
\hline 19 & 155 & 3,33 & 1,123 & 3,00 & 3,16 & 1,183 & 3,00 \\
\hline 20 & 155 & 3,25 & 1,054 & 3,00 & 3,19 & 0,947 & 3,00 \\
\hline 21 & 155 & 2,80 & 1,101 & 3,00 & 2,84 & 0,950 & 3,00 \\
\hline 22 & 155 & 3,35 & 0,985 & 3,00 & 3,42 & 0,993 & 3,00 \\
\hline 23 & 155 & 2,88 & 1,134 & 3,00 & 3,10 & 1,055 & 3,00 \\
\hline 24 & 155 & 3,70 & 0,975 & 4,00 & 3,62 & 1,015 & 4,00 \\
\hline
\end{tabular}




\begin{tabular}{|c|c|c|c|c|c|c|c|}
\hline 25 & 155 & 2,31 & 1,176 & 2,00 & 2,35 & 1,036 & 2,00 \\
\hline 26 & 155 & 3,94 & 1,030 & 4,00 & 3,66 & 1,159 & 4,00 \\
\hline 27 & 155 & 2,61 & 1,170 & 3,00 & 2,83 & 1,152 & 3,00 \\
\hline 28 & 155 & 2,37 & 1,058 & 2,00 & 2,50 & 1,107 & 3,00 \\
\hline 29 & 155 & 3,27 & 1,136 & 3,00 & 3,41 & 1,079 & 3,00 \\
\hline 30 & 155 & 3,50 & 1,065 & 4,00 & 3,63 & 1,033 & 4,00 \\
\hline 31 & 155 & 2,83 & 1,194 & 3,00 & 2,77 & 1,035 & 3,00 \\
\hline 32 & 155 & 3,25 & 1,186 & 3,00 & 3,00 & 1,117 & 3,00 \\
\hline 33 & 155 & 2,52 & 1,229 & 2,00 & 2,46 & 1,889 & 2,00 \\
\hline 34 & 155 & 2,95 & 1,005 & 3,00 & 2,86 & 0,947 & 3,00 \\
\hline 35 & 155 & 3,21 & 0,919 & 3,00 & 3,17 & 0,979 & 3,00 \\
\hline 36 & 155 & 2,79 & 1,049 & 3,00 & 2,67 & 1,020 & 3,00 \\
\hline
\end{tabular}

Berdasarkan tabel 15 dapat dilihat persentase kecenderungan responden dalam memilih padanan kata tersebut. Poin 1 menyatakan bahwa responden menganggap bahwa akuntansi pemerintah cenderung bersifat tetap. Untuk poin 2 responden beranggapan netral terhadap akuntansi pemerintahan apakah bersifat pengulangan atau akuntansi pemerintahan tersebut adalah suatu variasi.

Poin 3 responden beranggapan bahwa akuntansi pemerintahan merupakan aturan yang diterapkan. Hal ini didukung oleh pendapat dari Holmes (1989) yang mengungkapkan bahwa informasi akuntansi yang digunakan harus sesuai dengan undang-undang dan peraturan yang sedang berlaku. Indonesia saat ini telah menggunakan Peraturan Pemerintah Nomor 71 Tahun 2010 tentang Standar Akuntansi Pemerintahan.

Poin 4 responden beranggapan netral untuk akuntansi pemerintahan apakah akuntansi pemerintah bersifat membosankan atau menarik. Poin 5 responden juga memilih netral apakah akuntansi pemerintahan itu adalah ilmu yang menantang atau mudah. Poin 6 responden memilih netral untuk akuntansi pemerintahan apakah akuntansi pemerintahan bersifat menjemukan atau menyenangkan.

Poin 7 responden memilih netral untuk akuntansi pemerintahan apakah bersifat fleksibel atau bersifat sistematis. Akuntansi pemerintahan tidak dapat dikatakan bersifat fleksibel karena terikat oleh aturan dalam perundang-undangan dan perumusan strategi akuntansi pemerintahan pun juga dapat bersifat tidak sistematis. Poin 8 responden lebih beranggapan bahwa akuntansi pemerintahan memerlukan interaksi dengan orang lain. Pernyataan ini didukung oleh teori peran (role theory) yang dapat menjelaskan bagaimana akuntansi dan perilaku individu di dalam suatu organisasi akan saling mempengaruhi sehingga terjadilah interaksi antara orang-orang yang ada dalam suatu organisasi.

Pada poin 9 responden memilih netral antara kesesuaian atau kestabilan. Poin 10 responden juga memilih netral apakah akuntansi pemerintahan bersifat dinamis atau stabil. Poin 11 responden cenderung menilai bahwa akuntansi lebih berdasarkan pada standar operasional prosedur. Hal ini karena akuntansi pemerintahan harus terstruktur, sesuai dengan standar operasional prosedur serta memenuhi prinsip akuntansi yang diterima umum agar menciptakan kesesuaian antara pengguna akuntansi yang satu dengan yang lainnya sehingga informasi keuangan yang dihasilkan dapat diperbandingkan dan memenuhi kebutuhan dari pengguna informasi tersebut. 
Poin 12 responden beranggapan netral apakah akuntansi pemerintah adalah ekstrovert atau introvert. Akuntansi pemerintah dapat bersifat terbuka atau sebaliknya. Poin 13 responden menganggap akuntansi pemerintah bersifat konseptual karena akuntansi pemerintah disusun secara terperinci, terencana, punya landasan teori yang kuat serta manfaat yang jelas. Poin 14 responden memilih akuntansi pemerintah itu adalah suatu penyesuaian karena akuntansi pemerintah harus menyesuaikan apa yang tercatat dengan kenyataannya pada akhir periode tanpa memerlukan suatu inovasi yang baru.

Poin 15 responden menganggap bahwa akuntansi pemerintahan harus selalu menampilkan, menyajikan dan memaparkan informasi berdasarkan fakta yang ada. Poin 16 responden menganggap akuntansi pemerintahan bersifat pasti karena telah diatur oleh standar. Poin 17 responden beranggapan bahwa akuntansi pemerintahan adalah suatu ilmu yang terencana dan dapat berkelanjutan karena telah diatur sebelumnya, akuntansi pemerintah bukanlah sesuatu yang bersifat spontan. Poin 18 responden menganggap netral apakah akuntansi pemerintahan berorientasi pada orang atau berhubungan dengan angka-angka.

Poin 19 responden cenderung memilih akuntansi pemerintah bersifat teoritis, Suwardjono (1989) mendefinisikan akuntansi sebagai suatu bidang ilmu (science) yang berarti dalam akuntansi terdapat teori. Poin 20 responden memilih netral apakah akuntansi pemerintah bersifat membosankan atau mengasyikkan. Poin 21 responden memilih netral apakah akuntansi pemerintahan bersifat menarik atau membosankan. Poin 22 responden memilih netral apakah akuntansi pemerintahan bersifat abstrak atau konkret.

Poin 23 responden beranggapan netral apakah akuntansi pemerintahan bersifat efektivitas atau efisiensi karena akuntansi haruslah bersifat efektif, efisien dan ekonomis. Penyelesaian yang efektif belum tentu efisien begitupun sebaliknya, sehingga efektivitas dan efisiensi dalam akuntansi pemerintah harus diterapkan beriringan. Poin 24 responden beranggapan bahwa akuntansi pemerintahan adalah profesi yang lebih mengandalkan logika. Hendriksen (2000) mengungkapkan bahwa akuntansi adalah penalaran logis dalam bentuk seperangkat yang luas.

Poin 25 responden lebih menganggap bahwa akuntansi pemerintah membutuhkan ketelitian. Ketelitian yang tinggi sangat dibutuhkan didalam siklus akuntansi terutama pembukuan agar tidak terjadi kesalahan dikemudian hari akibat dari kelalaian karena informasi akuntansi sangat berpengaruh dalam pengambilan keputusan. Poin 26 responden lebih memilih bahwa akuntansi pemerintah harus sesuai dengan peraturan. Hal ini dikarenakan akuntansi pemeritnah memiliki suatu standar yang disebut dengan standar akuntansi pemerintahan yang terdiri dari peraturan, teknik dan prinsip untuk mengatur keseragamannya.

Poin 27 reponden memilih netral apakah akuntansi pemerintah bersifat detail atau ikhtisar. Akuntansi pemerintah harus disusun secara detail dan dilakukan pengikhtisaran setelah pencatatan dan pengklasifikasian. Poin 28 responden memilih netral apakah akuntansi pemerintah bersifat tepat atau tidak tepat. Poin 29 responden beranggapan netral apakah akuntansi pemerintah merupakan tampilan alternatif atau merupakan standar seragam.

Poin 30 responden menganggap netral apakah akuntansi pemerintahan bersifat berubahubah atau bersifat tetap, misalnya standar dan aturan yang digunakan dalam akuntansi pemerintah dapat saja berubah sesuai dengan perkembangan dan tuntutan masyarakat. Poin 31 responden menganggap netral apakah akuntansi pemerintah bersifat metodis mencari kebenaran untuk menghindari penyimpangan atau merupakan sesuatu yang baru.

Poin 32 responden memilih netral apakah akuntansi pemerintah adalah pencatatan atau pengambilan keputusan sebab harus ada pencatatan terlebih dahulu untuk menghasilkan laporan keuangan agar dapat dijadikan pedoman untuk pengambilan keputusan, sistem pencatatan yang 
digunakan di Indonesia saat ini adalah sistem akrual. Poin 33 responden lebih beranggapan bahwa akuntansi pemerintah lebih mengutamakan kepentingan organisasi, sebab tujuan utama dari akuntansi pemerintahan adalah berorientasi pada kepentingan publik bukan semata-mata mencari keuntungan (Arif, 2002).

Poin 34 responden memilih netral apakah akuntansi pemerintah bergengsi atau biasa saja karena masih ada bagian akuntansi lainnya seperti akuntansi keuangan dan akuntansi manajemen. Poin 35 responden memilih netral apakah akuntansi pemerintah bisa diubah atau tidak dapat diubah. Poin 36 respoden juga memilih netral apakah akuntansi pemerintah lebih bersifat matematis atau lisan sebab akuntansi pemerintah sangat bersangkutan dengan matematika dan berkenaan juga dengan kata-kata yang diucapkan.

Berdasarkan tabel 5 dapat dilihat rata-rata, standar deviasi dan nilai tengah dari jawaban responden yang lebih cenderung menjawab netral. Jumlah responden adalah 155 orang untuk masing-masing angkatan.

\section{Paired Sample T-Test}

Metode analisis data yang digunakan analisis uji beda. Berdasarkan penelitian yang telah dilakukan didapatkan hasil sesuai dengan tabel berikut :

\begin{tabular}{|c|c|c|c|c|c|c|c|c|}
\hline & \multicolumn{8}{|c|}{$\begin{array}{c}\text { Tabel } 6 \\
\text { Hasil Uji Beda } \\
\text { Paired Sample T-Test }\end{array}$} \\
\hline & \multicolumn{5}{|c|}{ Paired Differences } & \multirow[t]{3}{*}{$\mathbf{t}$} & \multirow[t]{3}{*}{ df } & \multirow{3}{*}{$\begin{array}{l}\text { Sig. (2) } \\
\text { tailed) }\end{array}$} \\
\hline & \multirow[t]{2}{*}{ Mean } & \multirow[t]{2}{*}{$\begin{array}{c}\text { Std. } \\
\text { Deviati } \\
\text { on }\end{array}$} & \multirow[t]{2}{*}{$\begin{array}{c}\text { Std. } \\
\text { Error } \\
\text { Mean }\end{array}$} & \multicolumn{2}{|c|}{$\begin{array}{l}\text { 95\% Confidence } \\
\text { Interval of the } \\
\text { Difference }\end{array}$} & & & \\
\hline & & & & Lower & Upper & & & \\
\hline $\begin{array}{l}\text { Mahasiswa } \\
2016- \\
\text { Mahasiswa } \\
2015\end{array}$ & ,29032 & $\begin{array}{c}4,7631 \\
8\end{array}$ & ,38259 &,- 46548 & 1,04612 & ,759 & 154 & ,449 \\
\hline
\end{tabular}

Dari tabel di atas diketahui bahwa nilai signifikansi 2-tailed adalah sebesar 0,449 > 0,05, jadi Ho diterima dan Ha ditolak. Berarti bahwa tidak terdapat perbedaan yang signifikan antara sebelum dan sesudah mengikuti mata kuliah akuntansi pemerintahan.

\section{PEMBAHASAN}

Berdasarkan hasil uji hipotesis yang dilakukan dalam penelitian ini ditemukan bahwa tidak terdapat perbedaan persepsi minat yang signifikan dalam berkarir antara mahasiswa yang sudah dan belum menyelesaikan mata kuliah akuntansi pemerintahan. Responden sudah mengenal dan menyukai profesi di bidang akuntansi pemerintahan ini baik sebelum maupun sesudah menyelesaikan mata kuliah akuntansi pemerintahan. Berdasarkan hasil kuesioner yang telah disebar diketahui banyak responden yang berminat untuk berkarir di bidang akuntansi pemerintahan.

Hal ini sedikit tidak sesuai dengan penelitian yang dilakukan Martin (2007) yang menjelaskan kurangnya minat mahasiswa Amerika untuk bekerja di peemrintahan karena masyarakat Amerika lebih menyukai berkarir di perusahaan swasta dibanding sektor pemerintahan. Penelitian Djamika (1995) dan penelitian Novianti (2007) menjelaskan 
bahwasanya di Indonesia berprofesi sebagai pegawai pemerintah adalah pekerjaan yang banyak diminati masyarakatnya sehingga sebelum meyelesaikan pendidikan akuntansi pemerintahan pun responden dalam penelitian ini sudah tidak asing lagi dan sudah mengenali profesi di bidang pemerintahan.

Meskipun tidak terdapat perbedaan antara responden yang sudah dan yang belum menyelesaikan mata kuliah akuntansi pemerintahan namun ternyata responden sangat berantusias sekali untuk berkarir di bidang pemerintahan ini. Rata-rata mahasiswa S1 akuntansi berminat untuk berkarir di bidang akuntansi pemerintahan karena pekerjaan ini dinilai memiliki potensi penghasilan awal yang tinggi, memberikan keamanan finansial, memiliki potensi penghasilan jangka panjang yang tinggi, memberikan fleksibilitas dalam masalah keseimbangan kehidupan kerja serta pekerjaan di bidang pemerintah memberikan kemaanan kerja yang terjamin.

Berdasarkan hasil uji statistik deskriptif juga tidak terlihat perbedaan yang terlalu mencolok tentang pendapat responden terhadap akuntansi pemerintahan. Terdapat 36 pasang kata yang saling berlawanan dimana responden diminta untuk memilih pandangan mereka terkait akuntansi pemerintahan seperti yang terdapat pada tabel 7. Berdasarkan tabel 7 dapat dilihat berbagai pandangan responden terhadap akuntansi pemerintahan. Responden menganggap akuntansi pemerintahan adalah ilmu pasti yang berdasarkan teori-teori, dijalankan sesuai dengan aturan-aturan yang berlaku karena akuntansi pemerintahan memiliki standar akuntansi pemerintahan yang mengaturnya. Akuntansi pemerintahan mengutamakan manfaat bagi organisasi dan saling berinteraksi dengan orang lain. Reponden tidak bisa memutuskan apakah auntansi pemerintahan bersifat membosankan atau menarik tetapi mereka tetap tertarik untuk bekerja di bidang ini.

Terdapat beberapa jenis profesi di bidang akuntansi pemerintahan yang dapat menjadi pilihan profesi bagi lulusan akuntansi S1, dalam penelitian ini diberikan beberapa pilihan profesi kemudian responden diminta untuk memilih profesi apa yang paling diminati jika kelak akan berkarir di bidang pemerintahan. Jawaban tersebut kemudian di list dan dihitung secara manual seperti yang terdapat pada tabel 8. Dari daftar list pada tabel, diketahui profesi yang paling banyak diminati adalah auditor internal dengan nilai persentase sebesar 52,90\% atau sekitar 164 orang responden karena responden cukup mengenal tuntutan yang harus dipenuhi dari profesi ini. Akuntan pajak juga diminati responden selanjutnya dengan nilai persentase sebesar $45,8 \%$ atau sekitar 142 orang responden dengan alasan pekerjaan ini memiliki potensi penghasilan yang cukup tinggi.

Profesi yang paling kurang diminati adalah penyusun rencana kebutuhan rumah tangga dan perlengkapan dengan nilai persentase sebesar $4,84 \%$ atau hanya 15 orang responden yang memilih. Kurangnya minat pada profesi ini karena profesi ini kurang dikenali responden.

Tabel 7

Pandangan Responden terhadap Akuntansi Pemerintahan

\begin{tabular}{rlrrrrrl}
\hline No & Padanan Kata & $\mathbf{1}$ & $\mathbf{2}$ & $\mathbf{3}$ & $\mathbf{4}$ & $\mathbf{5}$ & Padanan Kata \\
\hline 1 & Solusi Kreatif & $9 \%$ & $12 \%$ & $25 \%$ & $31 \%$ & $24 \%$ & Tetap \\
2 & Pengulangan & $11 \%$ & $25 \%$ & $35 \%$ & $20 \%$ & $9 \%$ & Variasi \\
3 & Ide Baru & $3 \%$ & $8 \%$ & $25 \%$ & $36 \%$ & $27 \%$ & Aturan yang diterapkan \\
4 & Membosankan & $4 \%$ & $16 \%$ & $40 \%$ & $28 \%$ & $11 \%$ & Menarik \\
5 & Menantang & $7 \%$ & $22 \%$ & $49 \%$ & $15 \%$ & $6 \%$ & Mudah \\
6 & Menjemukan & $3 \%$ & $18 \%$ & $45 \%$ & $25 \%$ & $9 \%$ & Menyenangkan
\end{tabular}




\begin{tabular}{|c|c|c|c|c|c|c|c|}
\hline 7 & Fleksibel & $5 \%$ & $13 \%$ & $34 \%$ & $33 \%$ & $15 \%$ & Sistematis \\
\hline 8 & Tersendiri & $5 \%$ & $11 \%$ & $20 \%$ & $39 \%$ & $24 \%$ & Interaksi dengan orang lain \\
\hline 9 & Kesesuaian & $10 \%$ & $20 \%$ & $30 \%$ & $29 \%$ & $11 \%$ & Keaslian \\
\hline 10 & Dinamis & $4 \%$ & $15 \%$ & $37 \%$ & $33 \%$ & $12 \%$ & Stabil \\
\hline 11 & Standar Operasional Prosedur & $18 \%$ & $30 \%$ & $28 \%$ & $18 \%$ & $6 \%$ & Solusi baru \\
\hline 12 & Ekstrovert & $7 \%$ & $15 \%$ & $44 \%$ & $25 \%$ & $10 \%$ & Introvert \\
\hline 13 & Konseptual & $12 \%$ & $28 \%$ & $25 \%$ & $25 \%$ & $10 \%$ & Analitis \\
\hline 14 & Inovasi & $8 \%$ & $12 \%$ & $31 \%$ & $36 \%$ & $13 \%$ & Penyesuaian \\
\hline 15 & Intuisi & $2 \%$ & $10 \%$ & $25 \%$ & $38 \%$ & $25 \%$ & Fakta \\
\hline 16 & Ragu-ragu & $3 \%$ & $8 \%$ & $26 \%$ & $35 \%$ & $28 \%$ & Pasti \\
\hline 17 & Terencana & $20 \%$ & $36 \%$ & $22 \%$ & $13 \%$ & $9 \%$ & Spontan \\
\hline 18 & Berorientasi pada orang & $12 \%$ & $19 \%$ & $28 \%$ & $23 \%$ & $17 \%$ & Angka-angka \\
\hline 19 & Praktis & $9 \%$ & $16 \%$ & $30 \%$ & $31 \%$ & $14 \%$ & Teoritis \\
\hline 20 & Membosankan & $6 \%$ & $13 \%$ & $45 \%$ & $26 \%$ & $11 \%$ & Mengasyikkan \\
\hline 21 & Sangat Menarik & $12 \%$ & $20 \%$ & $48 \%$ & $14 \%$ & $6 \%$ & Membosankan \\
\hline 22 & Abstrak & $4 \%$ & $10 \%$ & $42 \%$ & $30 \%$ & $14 \%$ & Konkret \\
\hline 23 & Efektivitas & $12 \%$ & $16 \%$ & $43 \%$ & $21 \%$ & $9 \%$ & Efisiensi \\
\hline 24 & Imajinasi & $3 \%$ & $8 \%$ & $29 \%$ & $38 \%$ & $21 \%$ & Logika \\
\hline 25 & Teliti & $27 \%$ & $31 \%$ & $28 \%$ & $9 \%$ & $5 \%$ & Dangkal \\
\hline 26 & Tidak bisa diprediksi & $3 \%$ & $11 \%$ & $23 \%$ & $31 \%$ & $33 \%$ & Sesuai dengan peraturan \\
\hline 27 & Detail & $16 \%$ & $27 \%$ & $33 \%$ & $14 \%$ & $9 \%$ & Ikhtisar \\
\hline 28 & Tepat & $23 \%$ & $29 \%$ & $34 \%$ & $10 \%$ & $4 \%$ & Tidak tepat \\
\hline 29 & Tampilan Alternatif & $7 \%$ & $12 \%$ & $39 \%$ & $25 \%$ & $17 \%$ & Standar seragam \\
\hline 30 & Berubah & $4 \%$ & $10 \%$ & $36 \%$ & $28 \%$ & $22 \%$ & Tetap \\
\hline 31 & Metodis & $15 \%$ & $22 \%$ & $40 \%$ & $16 \%$ & $8 \%$ & Sesuatu yang baru \\
\hline 32 & Pencatatan & $10 \%$ & $18 \%$ & $34 \%$ & $25 \%$ & $13 \%$ & Pengambilan Keputusan \\
\hline 33 & Manfaat Organisasi & $24 \%$ & $28 \%$ & $29 \%$ & $13 \%$ & $6 \%$ & Mencari Keuntungan \\
\hline 34 & Bergengsi & $9 \%$ & $19 \%$ & $52 \%$ & $14 \%$ & $7 \%$ & Biasa \\
\hline 35 & Bisa diubah & $4 \%$ & $13 \%$ & $53 \%$ & $18 \%$ & $11 \%$ & Tidak dapat diubah \\
\hline 36 & Matematis & $16 \%$ & $18 \%$ & $49 \%$ & $12 \%$ & $5 \%$ & Lisan \\
\hline
\end{tabular}

Sumber : Data primer yang diolah, 2018

Tabel 8

Profesi yang Paling Diminati di bidang Akuntansi Pemerintahan

\begin{tabular}{clrr}
\hline No & \multicolumn{1}{c}{ Jenis Profesi } & Jumlah & Persentase \\
\hline 1 & Akuntan Pendidik atau Tenaga Pengajar & 76 & $24,52 \%$ \\
2 & Auditor Internal & 164 & $52,90 \%$ \\
3 & Auditor Eskternal & 122 & $39,35 \%$ \\
4 & Penilai Pemerintah & 50 & $16,13 \%$ \\
5 & Akuntan Pajak & 142 & $45,81 \%$ \\
6 & Analis Berkas Sengketa & 24 & $7,74 \%$ \\
7 & Analis Kebijakan Lelang & 20 & $6,45 \%$ \\
8 & Analis Keuangan & 78 & $25,16 \%$ \\
9 & Analis Pengelolaan Kekayaan Negara & 56 & $18,06 \%$ \\
10 & Kustodian Kekayaan Negara & 19 & $6,13 \%$ \\
11 & Pemeriksaan Data Profesi Keuangan & 38 & $12,26 \%$
\end{tabular}




\begin{tabular}{rlrr}
12 & Pemeriksa Kekayaan Negara & 45 & $14,52 \%$ \\
13 & Penilai Properti & 37 & $11,94 \%$ \\
14 & Penyusun Rencana Kebutuhan Rumah Tangga & 15 & $4,84 \%$ \\
& dan Perlengkapan & & \\
15 & Pengawas Penerimaan Uang Negara & 62 & $20 \%$ \\
16 & Pengawas Pengeluaran Uang Negara & 30 & $9,68 \%$ \\
17 & Bendahara Umum & 69 & $22,26 \%$ \\
18 & Bendahara Khusus & 30 & $9,68 \%$ \\
19 & Akuntan Keuangan Daerah & 65 & $20,97 \%$ \\
20 & Pengelola Keuangan Daerah & 45 & $14,52 \%$ \\
21 & Administrasi Keuangan & 51 & $16,45 \%$ \\
\hline
\end{tabular}

Sumber : Data primer yang diolah, 2018

\section{PENUTUP \\ Kesimpulan}

Berdasarkan hasil temuan penelitian dan pengujian hipotesis yang telah dilakukan dapat disimpulkan bahwa :

1. Tidak terdapat perbedaan yang signifikan mengenai minat mahasiswa untuk berkarir di bidang akuntansi pemerintahan antara sebelum dengan sesudah diselesaikannya mata kuliah akuntansi pemerintahan.

2. Mahasiswa S1 akuntansi cenderung berminat untuk berkarir di bidang akuntansi pemerintahan.

3. Profesi yang paling diminati mahasiswa S1 akuntansi jika berkarir di bidang akuntansi pemerintahan adalah sebagai auditor internal dan akuntan pajak.

\section{Keterbatasan}

Peneliti telah berusaha merancang dan mengembangkan penelitian sedemikian rupa, namun masih terdapat beberapa keterbatasan dalam penelitian ini yang masih perlu direvisi bagi penelitian selanjutnya, yaitu antara lain :

1. Penelitian ini dilakukan pada mahasiswa S1 akuntansi UNP dan UNAND sehingga hasil tidak dapat digeneralisasi untuk universitas lain.

2. Responden penelitian adalah mahasiswa S1 akuntansi dengan tahun masuk 2015 dan 2016 dengan asumsi mahasiswa tahun masuk 2016 telah menerima sedikit gambaran mengenai akuntansi pemerintahan sebelumnya dari mata kuliah lain misalnya seperti mata kuliah akuntansi sektor publik sehingga tidak terlihat adanya perbedaan.

3. Sedikitnya penelitian terdahulu yang mengangkat permasalahan yang sama sehingga cukup sulit untuk menemukan referensi yang mendukung penelitian ini.

\section{Saran}

Berdasarkan kesimpulan dan keterbatasan yang telah diuraikan, maka saran-saran yang dapat diberikan adalah sebagai berikut :

1. Bagi penelitian selanjutnya, hendaknya melakukan penelitian pada universitas-universitas lain baik negeri maupun swasta agar hasil yang diperoleh lebih berkualitas dan menambah kategori universitas yang akan dijadikan sampel penelitian.

2. Bagi penelitian selanjutnya, hendaknya melakukan penelitian pada mahasiswa yang baru masuk dengan asumsi belum mengenal akuntansi pemerintahan sama sekali. 


\section{DAFTAR PUSTAKA}

Adisasmita, R. (2011). Manajemen Pemerintah Daerah. Yogyakarta : Graha Ilmu.

ANS. (2015). Tuntutan terhadap Akuntabilitas Pemerintahan. https://tesisdisertasi.blogspot.com/2015/04/tuntutan-terhadap-akuntabilitas ， diakses 9 Juli 2018.

Aprilyan, L. A. (2011). Faktor-Faktor yang Mempengaruhi Mahasiswa Akuntansi dalam Pemilihan Karir Menjadi Akuntan Publik. Skripsi. Universitas Diponegoro Semarang.

Arif, B. dkk. (2002). Akuntansi Pemerintahan. Jakarta : Salemba Empat

Arikunto, S. (2006). Metodologi Penelitian. Yogyakarta : Bina Aksara

Averus, N. (2015). Analisis Persepsi Mahasiswa Akuntansi dalam Memilih Karir. Skripsi. Universitas Diponegoro

Bastian, I. (2010). Akuntansi Sektor Publik. Jakarta : Erlangga

Baswir, R. (2000). Akuntansi Pemerintahan Indonesia. Yogyakarta : BPFE-Yogyakarta.

Choirunisa, S. A. (2017). Pengaruh Penghargaan Finansial, Gender dan Lingkungan Kerja terhadap Minat Menjadi Akuntan Pemerintah. Skripsi. Universitas Negeri Yogyakarta

Dianpawpaw. (2013). Faktor-faktor Pemilihan Profesi Akuntan. https://dianpawpaw.wordpress.com/tag/akuntan-pemerintah/, diakses pada 9 Juli 2018.

Echols, J. M. dan Hasan, S. (1984). Kamus Inggris-Indonesia. Jakarta : Gramedia. Cet. XII.

Engstrom, J.H (1979). Public Sctor Accounting : Status and Extension. The Accounting Review, $54(4)$.

Gibson, et. al. (1997). Organisasi dan Manajemen (Perilaku-Struktur-Proses), Edisi Bahasa Indonesia. Jakarta : Erlangga.

Halim, A dan Damayanti, T. (2007). Manajemen Keuangan Daerah Pengelolaan Keuangan Daerah. Yokyakarta : UPP STIM YKPN.

Harianti, S. S. (2017). Pengaruh Penghargaan Finansial, Pertimbangan Pasar Kerja dan Lingkungan Keluarga terhadap Minat Menjadi Akuntan Publik. Skripsi. Universitas Negeri Padang.

Hauri, R. F. (2017). Alasan Mengapa Banyak Orang yang Ingin Menjadi PNS. http://puan.co/2017/09/12-alasan-mengapa-banyak-orang-yang-ingin-menjadi-pns/, diakses pada tanggal 26 September 2018.

Hendriksen, E. S. (2000). Teori Akuntansi. Jakarta : Penerbit Erlangga.

Holder. W.W (1978). Graduate Level Public Sector Accounting : Status and Forecast. The Accounting Review, 53(3),746-751.

Holmes, S. dan Nicholls, D. (1988). An Analysis of The Use of Accounting Information by Australian Small Business. Jurnal Bisnis Manajemen.

Hoque, Z. (2002). Using Journals Articles to Teach Public Sector Accounting in Higher Education. Journal of Accounting Education, 20(3), 139-161.

Ikatan Akuntan Indonesia. (2015). Akuntan Tingkatkan Kemakmuran Ekonomi Bangsa. http://iaiglobal.or.id/v03/berita-kegiatan/detailarsip-865, diakses pada 24 Agustus 2018.

Indriantoro, $\mathrm{N}$ dan Supomo. (2002). Metodologi Penelitian Bisnis untuk Akuntansi dan Manajemen. Edisi Pertama. Yogyakarta : BPFE.

Kam, V. (1989). Accounting Theory, 2nd Edition. Jhon Wily and Sons. Nem York.

Karim, F. (2013). Kenapa Orang Berebut jadi PNS. https://www.kompasiana.com/efki/5528cf7ef17e61e70b8b4569/kenapa-orang-berebutjadi-pns, diakses pada tanggal 20 September 2018 .

Keputusan Menteri dalam Negeri No. 29 tahun 2002 
Keputusan Presiden No. 68 tahun 1995

Kleinbaum, D.G. dan L. L. Kupper. (1978). Applied Regression Analysis and Other Multivariable Methods. Duxbury Press, Nort Scituate, Massachusetts.

Krah, R. Y dan Aveh, F. K. (2013). Public Sector Accounting Education : A Neglected Element of Public Financial Management Reforms in Ghana. International Journal of Governmental Financial Management.

Krismansimamora. (2011). Perkembangan profesi Akuntansi di Indonesia. https://krismansimamora.wordpress.com/2011/01/08/perkembangan-profesi-akuntansi-diindonesia/, diakses pada tanggal 13 Juli 2018

Lowensohn, S. H dan Reck, J. L. (2005). Methods and Resources to Increase Student Interest in Government Accounting. Jurnal of Public Budgeting Accounting and Financial Management, 17(2), 202-222.

Mahmudi. (2006). Manajemen Kinerja Sektor Publik. Yogyakarta: Akademi Manajemen Perusahaan YKPN.

Mardiasmo. (2006). Pewujudan Transparansi dan Akuntabilitas Publik Melalui Akuntansi Sektor Publik: Suatu Sarana Good Governance. Jurnal Akuntansi Pemerintah, 2(1).

Martin, R. B. dan Waymire, T.R. (2017). Filling the Demand for Municipal Government Accountants : The Benefits of a Governmental and Not-for-provit Accounting Course. Jurnal of Accounting Education.

Meliala, S.T, dkk. (2011). Akuntansi Sektor Publik. Jakarta : Semesta Media.

Mulyadi dan Puradiredja, K. (1998). Auditing Edisi ke 5 Jakarta : Penerbit Salemba Empat.

Mulyadi. (2001). Sistem Akuntansi. Edisi Ketiga. Jakarta : Salemba Empat.

Murphy, E. A. (2005). Trends and Challenges in Governmental Accounting Education. Journal of Government Financial Management, 55(2), 22-24.

Nordiawan, D dan Hertianti, A. (2010). Akuntansi Sektor Publik. Edisi Kedua. Jakarta : Salemba Empat.

Okezonefinance. (2017). Seberapa Besar Peluang Kerja Akuntan? Profesinya tak Tergantikan https://economy.okezone.com/read/2017/10/14/320/1795400/ seberapa-besar-peluangkerja-akuntan-profesinya-tak-tergantikan, diakses pada 12 Juni 2018.

Peraturan Pemerintah No. 105 tahun 2000 tentang Pengelolaan dan Pertanggungjawaban Keuangan Daerah.

Peraturan Pemerintah No. 30 tahun 2015 tentang Kenaikan Gaji PNS 2015.

Purwati, A. S dan Sari, Y.Y. (2015). Persepsi Mahasiswa Akuntansi terhadap Pemilihan Karier. Jurnal. Universitas Soedirman.

Rahayu, Sri dkk. (2003). Persepsi Mahasiswa Akuntansi Mengenai Faktor-Faktor yang Memepengaruhi Pemilihan Karir. Simposium Nasional Akuntansi VI. Surabaya

Rasmini, N. K. (2007). Faktor-Faktor yang berpengaruh pada Keputusan Pemilihan Profesi Akuntan Publik dan Non Akuntan Publik pada Mahasiswa Akuntansi di Bali. Buletin Studi Ekonomi, 12(3), 351-366.

Robbins, S. P. (2006). Perilaku Organisasi. Edisi ke Sepuluh. Jakarta : PT. Indeks Kelompok Gramedia.

Robbins, S. P. dan Judge, T.A. (2013). Perilaku Organisasi. Jakarta : Salemba Empat.

Saemann, P. G. dan Crooker, K. J. (1999). Student Perceptions of the Profession and It's Effect on Decision to Major Accounting. Journal of Accounting Education.

Salim, P. dan Salim, Y. (1991). Kamus Bahasa Indonesia Kontemporer. Jakarta : Modern English. 
Sarwono, S. W. (2008). Psikologi Remaja. Jakarta : PT Raja Grafindo Persada

Sawarjuwono, T. (2005). Produk Pendidikan Akuntansi di Masa Depan : Suatu Proses Antisipasi. Media Akuntansi.

Sekaran, U. (2006). Metode Penelitian untuk Bisnis I. Jakarta : Salemba Empat.

Sherazade, A. A. (2015). Akuntansi Pemerintahan. http://apriliaanestya.blogspot.com/2015/10/akuntansi-pemerintahan.html, diakses pada 9 Juli 2018.

Sims, R. Dan Sciulli N. (2007). Public Sector Accounting Education in Australia Universities : An Enploratoty Study. Sunway Aacademic Journal, 4, pp 45-58.

Sims, R., Sciulli N. Dan Demediuk P. (1997). Public Sector Accounting Content in Australian University Courses. Australian Society of Certified Practicing Accountants. Public Sector Accounting Centre of Excellence.

Slameto. (2010). Belajar dan Faktor yang Mempengaruhinya. Jakarta : Rineka Cipta.

Stamatiadis, F., Eriotis, N dan Vasiliou, D. (2009). Assessing Accrual Accounting Reform in Greek Publik Hospitals : An Empirical Investigation. International Journal of Economic Science and Applied Research, 4 (1), 153-184.

Subana, M dan Sudrajat. (2005). Dasar-Dasar Penelitian Ilmiah. Bandung : Pustaka Setia.

Sugiarto, I. dan Bagjana, I. F. (2013). Peran Akuntansi Pemerintah dalam Rangka Membangun Akuntabilitas, Transparansi dan Pemerintah Daerah. Jurnal. Sekolah Tinggi Hukum Bandung.

Sugiyono. (2014). Metode Penelitian Pendidikan Pendekatan Kuantitatif, Kualitatif, dan R\&D. Bandung : Alfabeta.

(2016). Metode Penelitian Pendidikan Pendekatan Kuantitatif, Kualitatif dan R\&D. Bandung : Alfabeta.

Sulistiani, D. (2012). Faktor-faktor yang Mempengaruhi Niat Mahasiswa Akuntansi untuk Berkarir sebagai Akuntan Publik. Skripsi. Universitas Diponegoro Semarang.

Surya, M. (1985). Psikologi Pendidikan. Bandung : Publikasi Juursan Psikologi Pendidikan dan Bimbingan Faklutas Ilmu Pendidikan IKIP.

Suwardjono. (1989). Akuntansi Pengantar 1 : Konsep Proses Penyusunan Laporan Keuangan, Pendekatan Sistem dan Terpadu. Yogyakarta : BPFE

Thoha, M. (2010). Perilaku Organisasi Konsep Dasar dan Aplikasinya. Rajawali Pers : Jakarta.

Trisnawati, M. Pengaruh Persepsi dan Motivasi terhadap Minat Mahasiswa Jurusan Akuntansi Fakultas Ekonomi dan Bahasa Universitas Brawijaya Berkarir di Bidang Perpajakan. Jurnal. Universitas Brawijaya.

Umar, H. (2002). Metode Penelitian dalam Aplikasi Pemasaran. Jakarta : PT. Gramedia Pustaka Utama.

Undang-Undang No. 12 tahun 2008 tentang Pemerintah Daerah.

Undang-Undang No. 17 tahun 2003 tentang Keuangan Negara.

Undang-Undang No. 43 tahun 1999 tentang Pokok-Pokok Kepegawaian.

Virmansyah. (2016). Plus Minus Pegawai Negeri dan Pegawai Swasta. https://www.ruangpegawai.com/motivasi/plus-minus-pegawai-negeri-dan-pegawaiswasta-1184, diakses pada 13 Juli 2018.

Vroom, Victor H. Work and Motivation. New York : John Willey \& Son, inc..

Wahyudi, J dan Mulyani, S. (2013). Analisis Persepsi Mahasiswa Akuntansi atas Reward, Pelatihan Profesional, Nilai Sosial, Lingkungan Kerja, Pertimbangan Pasar Kerja, Personalitas dan Kesetaraan Gender terhadap Pemilihan Karir sebagai Akuntan Publik. Jurnal. Universitas Padjajaran. 
Widodo, J. (2001). Good Governance : Akuntabilitas dan Kontrol Birokrasi. Surabaya : Insan Cendekiawan.

Yanti, N. (2014). Analisis Faktor-Faktor yang Mempengaruhi Mahasiswa Akuntansi dalam Pemilihan Karir Menjadi Akuntan Publik 